\title{
İlkokul çocuklarının harita çizimi ve okuma becerilerini ölçme ve değerlendirmeye yönelik bir vaka çalışması
}

\author{
Halil İbrahim Şenol ${ }^{* 1}$, Türkay Gökgöz²@ \\ ${ }^{1}$ Harran Üniversitesi, Mühendislik Fakültesi, Harita Mühendisliği Bölümü, Sanlıurfa, Türkiye \\ ${ }^{2}$ Yıldız Teknik Üniversitesi, İnşaat Fakültesi, Harita Mühendisliği Bölümü, İstanbul, Türkiye
}

\author{
Anahtar Kelimeler \\ Kartografya \\ Harita Aktiviteleri \\ Topolojik İlişkiler \\ Harita Becerileri
}

\begin{abstract}
ÖZ
$\mathrm{Bu}$ çalışmada, ilkokul öğrencilerinin harita çizimi ve okuma becerisi tespit edilmeye çalışılmıştır. Bu amaç doğrultusunda ilk olarak çocuklara evden okula geliş rotaları (ev-okul haritaları) çizdirilmiş ve sonuçlar çeşitli ölçütlere göre değerlendirilmiştir. İkinci olarak basılı bir Dünya haritasında gördüklerini aynen çizmeleri istenmiş ve sonuçlar yine çeşitli ölçütlere göre değerlendirilmiştir. Son olarak sınıfın belli bir yerine bir cisim saklanmış ve mevcut bir haritadan (yaklașık ölçekli sınıf planından) yararlanarak bu cismi bulmaları istenmiștir. Sonuç olarak, öğrenciler tarafından çizilen haritalarda (ev-okul ve Dünya haritaları) yaşla doğru orantılı bir nitelik artışı olmadığı ve çoğunluğunun orta nitelikte olduğu tespit edilmiștir. Bununla birlikte, harita kullanma becerisi bakımından öğrencilerin oldukça iyi oldukları gözlenmiştir.
\end{abstract}

\section{A case study for measuring and evaluating map skills of primary school children}

\section{Keywords}

Cartography

Map Activities

Topological Relations

Map Skills

\begin{abstract}
In this study, map drawing and reading skills of primary school students were tried to be determined. In accordance with this purpose, children were firstly given home-to-school arrival routes task (home-school maps) and the results were evaluated according to various criteria. Secondly, they were asked to draw exactly what they saw on a printed World map and the results were again evaluated according to various criteria. Finally, an object was hidden in a certain point of the class and they were asked to find the object by using an existing map (approximate scale class plan). As a result, it was found that the quality was not increasing in proportion to age in the maps drawn by students (home-school and World maps) and most of them were of medium quality. However, it was observed that the students were quite good in terms of using a map.
\end{abstract}




\section{Gíriş}

Piaget ve Inhelder'e (1956) göre çocuklar küçük yaşlardan itibaren etraflarında gördükleri nesneleri haritalar üzerinde ayırt edebilirler ve bu beceri, düzenli ve entelektüel gelişime paralel olarak artış gösterir. İlkokul çocuklarının harita becerilerini ölçme ve değerlendirmeye yönelik günümüze değin pek çok çalışma yapılmıştır. Bu çalışmalardan öne çıkanlar kronolojik olarak aşağıdaki gibi özetlenebilir.

Jahoda (1963) tarafından gerçekleștirilen çalışmada, çocuklar yaşlarına göre dört gruba $(6-7,9,9-11,11)$ ayrılmış ve "Glasgow nerede? İskoçya nerede? İskoçya nedir? Britanya nedir? Britanya'yı duydunuz mu? Ne olduğunu düşünüyorsunuz?" soruları sorulmuştur. Alınan cevaplar incelendiğinde çocukların coğrafi bilgi düzeyleri bakımından dört aşama olduğu tespit edilmiştir: Glasgow'un bilinmediği birinci aşama, Glasgow'un bilindiği fakat İskoçya'nın bir parçası olarak bilinmediği ikinci aşama, Glasgow'un İskoçya'nın bir parçası olarak bilindiği fakat Britanya'nın bir parçası olarak bilinmediği üçüncü aşama ve Glasgow-İskoçyaBritanya ilișkisinin bilindiği dördüncü așama. Çalıșma sonucunda 6-7 yaş grubundaki çocukların sadece \%14'ünün üçüncü aşamada ve sadece \%6'sının dördüncü aşamada oldukları görülmüştür. Bu nedenle bu yaş grubunun mekânsal ilişki algısının zayıf olduğu sonucuna varılmıștır.

Towler ve Nelson (1968) tarafından yapılan çalışma, ilkokulda mekânsal kavramların geliştirilmesine ilişkin deneysel çalışmanın bir bölümüdür. Burada incelenmek üzere ölçek kavramı seçilmiştir. Çalışmaya 120 öğrenci katılmıştır. Çalışmada çocuklara iki farklı harita üzerinde farklı boyutlarda modellerle bir çiftlik kurmaları istenmiştir. Yapılan deney sonucunda, 10-11 yaşından küçük çocuklarda ölçek kavramının yeterince anlaşılmadığı ortaya konulmuştur.

Carswell (1970) tarafından yapılan çalışmada 4, 5 ve 6. sinıf öğrencilerinin topografik harita okuma ve yorumlama yetenekleri ile birlikte kişisel ve çevresel özelliklerinin bu yeteneklere etkisi araştırılmıştır. Bu yetenekleri ölçmek için harita okuma, yönlendirme, ölçek, yükseklik ve grid sistemi başlıkları altında 6 yetenek sınıfı oluşturulmuş ve eğitilmiştir. Eğitim öncesi ve sonrası yetenekler gözlemlenerek gruplar karşılaştırılmıştır. Harita eğitimi okul müfredatının bir parçası olmasına rağmen genel olarak çocukların haritaları yeterince okuyamadıkları gözlemlenmiştir. Sonuç olarak eğitimde kullanılacak harita ölçekleri konusunda araştırma yapılması ve öğretmenlerin harita teknikleri konusunda bilgilendirilmeleri önerilmiştir.

Towler (1970) çalışmasında, ilkokul çocuklarında mekânsal kavramların geliştirilmesine yönelik bir araştırmanın referans sistemleri kavramına ilişsin bölümünün raporunu sunmuştur. Elde edilen bulgular, bir referans sistemi kavramının geliştirilmesinin Piaget (1956) tarafından tarif edilen ontogenetik diziyi izlediğini göstermiştir. Konu hakkında daha çok araștırma yapılması gerektiğinden bahsedilmiştir.

Piche $(1977,1981)$ çalışmalarında, Piaget ve Inhelder (1956) ve Jahoda (1963) tarafindan kullanılan metotları analiz etmiştir. Londra'da 5-8 yaș arası 48 çocukla çalışılmış ve çizim, harita egzersizleri, coğrafi yapbozlar kullanılmıştır. Çocukların sadece $\% 10$ 'u Londra ile İngiltere'nin bağlantılı olduğunu anlamıștır. Piche, 6 yaşındaki çocukların adreslerini biliyor olsalar da bunun anlamını bilmediklerini tespit etmiştir.

Daggs (1986) çalışmasında, 6-7, 7-8 ve 8-9 yaş gruplarındaki çocuklarla sözlü ve grafik testler içeren ve büyük ölçekli fiziksel bir modelin kullanıldığı çeșitli çalışmalar yapmıştır. Sözlü test sonuçlarına göre birinci ve ikinci grup arasında farklılıklar olduğu, grafik test sonuçlarına göre ise her grupta farkllıklar olduğu tespit edilmiştir. Ayrıca, büyük ölçekli model kullanıldığında tüm grupların performanslarının geliştiği gözlemlenmiștir.

Trifonoff (1995) tarafından yapılan çalışmada, 2. sınıf öğrencilerinin tematik harita yapma yeteneklerini değerlendirmek için bir deney yapılmıştır. Öğrenciler farklı harita işaretlerini içeren ulusal ölçeklerdeki semt ve şehir haritalarını rastgele sırayla incelemişlerdir. Ayrıca, bu haritalar üzerinde çeşitli işaretler gösterilerek çocukların tepki süreleri tespit edilmiş ve harita algıları ölçülmeye çalışılmıştır. Elde edilen sonuçlar, harita görevlerinin bu yaş seviyesine uygun olduğunu göstermiştir.

Wiegand (1995) tarafından yapılan çalışmada, 7 farklı okuldan katılan 268 ilkokul öğrencisinden dünya haritası çizmeleri istenmiştir. Artan yaşla orantılı olarak gelişim gösteren bu haritalar puanlandırılmış ve sınıflandırılmıştır. Bu çalışmadan elde edilen sonuçlar, çocuklarda Dünya bilgisini ölçme ve değerlendirmeye dair diğer araştırmalarla karşılaştııılmıştır.

Harwood ve McShane (1996) tarafindan yapılan çalışmalarda, 5-6, 7-8 ve 9-10 yaş gruplarındaki çocukların Nuneaton-İngiltere-İngiliz Adaları-Avrupa arasındaki ilişkileri nasıl anladıkları üç farklı yöntem (harita, röportaj ve yapboz) kullanılarak araștırılmıștır. Seyahat tecrübesi olan çocuklarda bu testleri çözme başarılarının arttığı görülmüştür. Bu çalışmada; Piaget (1956), Jahoda (1963), Piche (1977-1981) ve Daggs'ın (1986) çalışmaları örnek alınmıştır.

Wiegand ve Stiell (1997) tarafından yapılan çalışmada, "Çocukların ülkeler ile ilgili ilk dikkat ettikleri, ülkelerin isimleridir." tezinden (Piaget, 1956) yola çıkılarak, 7-8 ve 10-11 yaşlarındaki 222 çocuk ile bir uygulama yapılmıștır. Çocuklara bildikleri ülkelerin isimleri sorulmuş ve bunları harita üzerinde göstermeleri istenmiştir. 10-11 yaş grubundaki çocukların daha başarılı oldukları görülmüştür. İsimlere dayalı coğrafya öğretiminin eğitimciler için çok daha avantajlı olacağı ifade edilmiștir.

Joshi, MacLean ve Carter (1999) tarafindan yapılan çalışmada, 7 ila 12 yaş arasındaki 93 çocuğun mekânsal ilişkileri ve çevreyi algılamaları ile ilgili bir anket sonuçları değerlendirilmiştir. Mekânsal ilişkileri ve çevreyi algılama bakımından yaşça büyük ve kelime dağarcığı geniş çocukların daha yetenekli olduğu, bununla birlikte bu yeteneklerin ana değişkenlerle (cinsiyet, yaş, vb.) bir ilgisi olmadığı tespit edilmiştir.

Harwood ve Usher (1999) tarafindan yapılan çalışmada, 8-9 yaşındaki çocuklardan rota belirleme amacı doğrultusunda kroki çizmeleri istenmiş ve çizim yetenekleri incelenmiștir. Piaget ve Inhalder'ın 1956 yılındaki çalışmalarında elde ettikleri sonuçları doğrular nitelikte sonuçlar elde edilmiş ve 11 yaşından küçük 
çocuklar için harita çizim becerisi kazandırmanın önemi hakkında șüpheler olduğundan bahsedilmiștir. Ayrıca, çocukların çizim becerilerinde kümülatif bir artış olduğu gözlenmiştir.

Harwood ve Rawlings (2001), çocukların el çizimleri üzerinde durmuşlardır. 10-11 yaşlarındaki 26 İngiliz çocuğun yaptığı haritalar analiz edildiğinde, șekilden çok, konum ve boyutları algılayabildikleri gözlemlenmiștir. Atlas üzerinde eğitimden sonra çocukların becerilerinde gözle görülür bir artış olduğu tespit edilmiştir.

Kızılçaoğlu (2007) tarafından, harita becerisinin insan hayatındaki öneminden bahsedilmiş ve öğrencilerin haritaları daha iyi kavramasıyla mekânsal bilgileri daha iyi analiz edecekleri ifade edilmiştir. $\mathrm{Bu}$ doğrultuda, harita becerilerini geliştirmek için çeşitli etkinlik örnekleri (haritalar üzerinde coğrafi sorular sorma, coğrafi bilgi edinme, coğrafi bilgiyi organize etme, coğrafi bilgiyi analiz etme, vb.) verilmiştir. Sonuç olarak şu tespit ve öneriler yapılmıştır: Öğrencilerin eksiklikleri ve gelişimleri ölçme ve değerlendirme yöntemleri sayesinde tespit edilebilir; ilkokul öğrencileri için becerilerin basamaklandırılarak kazandırılması gerekmektedir; ilkokul öğrencilerinin harita becerileri günlük hayatta kullanabilecekleri atlaslar ve basit içerikli haritalarla geliștirilebilir.

Weber ve diğerleri (2010) tarafindan yapılan çalışmada, İsviçre Dünya Atlası'nın internet üzerinde yayınlanan versiyonuna oyun kolları entegre edilerek, çocuklara ve gençlere hitap edebilirliği araştırılmıştır. Yapılan çalıșmaya katılanlar oyun kolları ile harita kullanımını öğrenirken daha çok eğlenmişler ve genelde bu oyun kollarına hâkim olan çocuklar haritayı daha kolay algılamışlardır. Sonuç olarak, haritada gezinme ve anlama bakımından hâkimiyetleri artmıştır.

Windiastuti (2012) tarafından Endonezya'da yapılan bir çalışmada, harita eğitiminin yetersizliği konusu üzerinde durulmuş ve "Çocukların ilgileri haritalar üzerine nasıl çekilir?" sorusu tartışılmıştır. Endonezyalılara göre ülkelerinin haritasını ve binlerce adası olan ülkenin her adasını bilmek her Endonezyalının borcudur. Her yıl belli yaş grupları arasında çocuklarla, harita yapma yarışmaları düzenlenmekte ve çocukların ilgisi canlı tutulmaya çalışılmaktadır.

Sönmez ve Aksoy (2013) tarafından yapılan çalışmada, Cumhuriyet'in ilan edilmesinden günümüze Türkiye'deki ilkokul programları öğrencilerin harita becerileri bakımından incelenmiștir. Araștırmada, betimsel tarama modeli kullanılmıștır. Sonuçta, Cumhuriyet'in ilk yıllarında öğrencilerin gözleri önündeki çevre referans alınmışken ilerleyen yıllarda kartografya bilimi ve teknolojiye bağlı olarak gelişim tespit edilmiştir. İlkokul programlarındaki harita içeriğinin zenginleştirilmesi, ders kitaplarında haritalara daha çok yer verilmesi, çeşitli konularda üretilmiş haritaların okullarda kurulacak coğrafya laboratuvarlarına yerleștirilmesi ve uygulama yapmak için çizim masaları kurulması önerilmiştir.

Hennerdal (2015) tarafından yapılan bir çalışmada, algılama yetisini kazanmış büyük çocukların ve yetişkinlerin harita algılama becerileri ölçülmüştür. Çalışmada katılımcılara, basılı bir Dünya haritasında, örneğin A noktasından yola çıkan bir uçağın hangi rotayı izleyerek ilerlemesi gerektiği sorulmuş ve cevaplar toplanmıştır. Çalışma sonunda, uygulamaya katılanların çoğunun harita üzerinde rota belirlerken Dünya'nın eğriliğini hesaba katmadıkları ortaya çıkmıştır.

Ooms ve diğerleri (2016) tarafından yapılan çalışmada ise gençlerin harita okuma becerisi ölçülmüştür. Çalışmada, yaşları, fiziki ve eğitim durumları farklı belli sayıda çocuğa beș harita ve bu beș haritayla ilgili toplamda yirmi soruluk beş soru kâğıdı dağıtılmış ve alınan sonuçlar istatiksel analizlerle incelenmiştir. Doğru cevap sayısının çocukların yaşları ve aldıkları eğitim ile doğru orantılı olduğu, fakat fiziki özelliklerinin buna hiçbir etkisinin olmadığı anlaşılmıştır.

Sena ve Carmo (2020) çalışmasında, Brezilya'daki akademik çalışmaların; Eğitim Bakanlığı tarafından önerilen resmi belgeleri, temel eğitimde harita öğretimini ve coğrafya lisans derslerinin müfredatını nasıl etkilediğini göstermektedir. Amaç, haritacılığın coğrafya öğretimindeki rolünü ve haritalarla öğrenmenin 1990'lardan itibaren Brezilya vatandaşı olma bilincine nasıl daha yoğun bir şekilde katkıda bulunduğunu ortaya koymaktır.

Şenol ve Gökgöz $(2018,2020)$ tarafından yapılan çalışmalarda ise anaokulu ve ortaokul öğrencilerinin harita algı ve becerilerini ölçülme ve değerlendirmeye yönelik olarak basılı ve kabartma haritalarla birlikte metinlerin de kullanıldığı çeşitli aktiviteler yapılmış ve elde edilen sonuçlara göre anaokulu ve ortaokul müfredatında harita eğitimine daha fazla yer verilmesi gerektiği vurgulanmıştır.

$\mathrm{Bu}$ çalışmada ise ilkokul öğrencilerinin yeryüzünün çok iyi bildikleri bir bölgesinin (yaşadıkları bölgenin) büyük ölçekli haritasını (ev-okul haritası) çizme ve yeryüzünün tamamının küçük ölçekli haritasını (Dünya haritası) çizme becerisini ölçme amacı doğrultusunda çeşitli aktiviteler gerçekleştirilmiştir. Ayrıca, harita okuma becerisini ölçme amacı doğrultusunda bir define haritası aktivitesi gerçekleştirilmiştir.

\section{YÖNTEM}

Aktiviteler, Kocaeli ili Karamürsel ilçesinde faaliyet gösteren Amiral Karamürsel İlkokulu öğrencileri ile gerçekleştirilmiştir. Aktivitelere 3 adet birinci sınıf, 1 adet ikinci sınıf, 1 adet üçüncü sınıf ve 1 adet dördüncü sınıf olmak üzere toplam 6 sınıfta 133 öğrenci katılmıştır.

Her aktivite öncesi gerçekleştirilen hazırlık aşamasında çocuklara sorulan "Harita nedir?" ve "Harita ne işe yarar?" gibi sorular ve çocukların verdiği "Yolda yön bulmaya yarar., "Define haritası vardır.", "Ülkelerin yerini göstermeye yarar." ve "Seyahat ederken kullanırız." gibi yanıtlar üzerinden çocukların mevcut bilgileri kabaca ölçülmeye ve kısaca bilgilendirilmeye çalışılmıştır.

\subsection{Birinci Aktivite: Ev-Okul Haritası Çizimi}

Çocuklar harita bilgisine sahip olmasalar da mekânsal ilişkilere dair bilgilere sahiptirler (Piaget ve Inhelder, 1956). Bu nedenle, çocukların zihinlerinde, evleri ve okulları arasındaki ilgi noktası olarak belirleyebilecekleri objeler bulunmaktadır. Çocuklardan evden okula nasıl gittiklerini zihinlerinde canlandırmaları ve yol üzerindeki ilgi noktalarını düşünmeleri istenmiştir. İlgi 
noktaları ile kastedilenin market, camii, karakol ve okul gibi nesneler olduğu ifade edilmiștir. Cocuklardan, evden okula giderken izledikleri yolu ve bu yol üzerindeki ilgi noktalarını boş kâğıtlara çizmeleri istenmeden önce, uygulamanın daha iyi anlaşılması için bir örnek harita tahtaya çizilmiştir (Şekil 1). Çocuklar iyice düşündükten ve tahtadaki haritayı inceledikten sonra boş kâğıtlar dağıtılmış ve kendi haritalarını çizmeleri istenmiştir. Ayrıca, haritalarında gösterecekleri varlıkları boyama yoluyla renklendirebilecekleri de ifade edilmiștir.

Ögrenciler tarafından çizilen ev-okul haritaları Tablo 1'deki ölçütlere göre incelenmiş ve her bir ölçüte göre 03 arası puanlar (0: Yok, 1: Az, 2: Orta, 3: Oldukça) verilmiştir.

Ölçütlere göre verilen puanların toplamları hesaplanmış, başarı aralıkları (İyi: 2-10, Orta: 1-2, Zayıf:
0-1) belirlenmiş ve başarı analizleri yapılmıştır (Tablo 1). Ölçütlere göre analiz sonuçları sınıf bazında grafik olarak Şekil 2, 3, 4 ve 5'te gösterilmiştir.

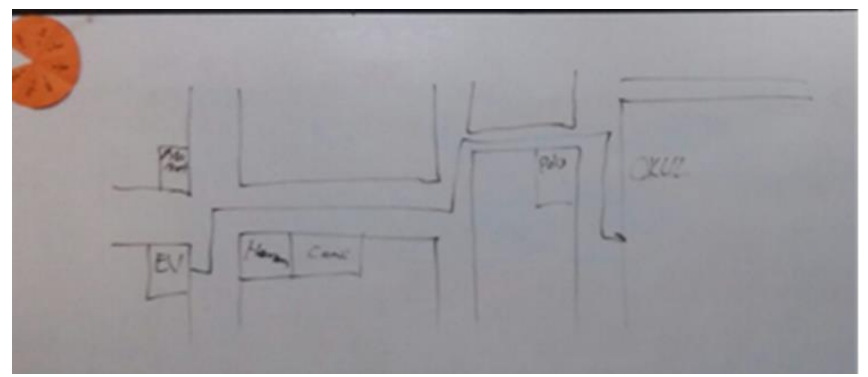

Şekil 1. Birinci aktivite için örnek olarak sınıf tahtasına çizilen ev-okul haritası

Tablo 1. Ev-okul haritası değerlendirme ölçütlerine göre iyi, orta, zayıf nitelikte harita yüzdeleri

\begin{tabular}{|c|c|c|c|}
\hline Değerlendirme Ölçütleri & İyi & Orta & Zayıf \\
\hline Geometri: Nokta, Çizgi, Poligon & 28,6 & 59,4 & 12 \\
\hline Renk: Siyah-Beyaz, Renkli & 5,3 & 15,8 & 78,9 \\
\hline Renk Seçimi: Doğru, Kısmen, Yanlıș & 3,8 & 5,3 & 91 \\
\hline Boyama & 2,3 & 6,8 & 91 \\
\hline Tarama & 0 & 1,5 & 98,5 \\
\hline Topolojik İlișkiler: Doğru, Kısmen, Yanlıș & 6,1 & 18 & 75,9 \\
\hline Yol: Tek Çizgi, Çift Çizgi: (Tek Şeritli, Çift Şeritli) & 2,3 & 29,3 & 68,4 \\
\hline Yol Ağı: Var, Kısmen, Yok & 6 & 15,8 & 78,2 \\
\hline Bina: 2 Boyutlu: (Planimetrik, Tek Cepheli), 3 Boyutlu (Perspektif) & 1,5 & 23,3 & 75,2 \\
\hline Bitki Örtüsü (Ağaç, vb.) & 0,8 & 2,3 & 97 \\
\hline Gökyüzü (Güneș, Ay, Bulut) & 0,8 & 3 & 96,2 \\
\hline Sembol (Bayrak, vb.) & 0 & 3 & 97 \\
\hline Yazı & 1,5 & 9 & 89,5 \\
\hline Taşıt (Otomobil, Bisiklet, Uçak, vb.) & 0 & 2,3 & 97,7 \\
\hline Canlı (İnsan, Hayvan) & 0 & 3,8 & 96,2 \\
\hline Akarsu: Tek Çizgi, Çift Çizgi & 1,5 & 0,8 & 97,7 \\
\hline Köprü & 0,8 & 0,8 & 98,4 \\
\hline Deniz & 0 & 3,8 & 96,2 \\
\hline Sınır Çizgisi (Park, Bahçe, vb.) & 1,5 & 3 & 95,5 \\
\hline Yükselti (Dağ, Tepe) & 0 & 0,8 & 99,2 \\
\hline
\end{tabular}

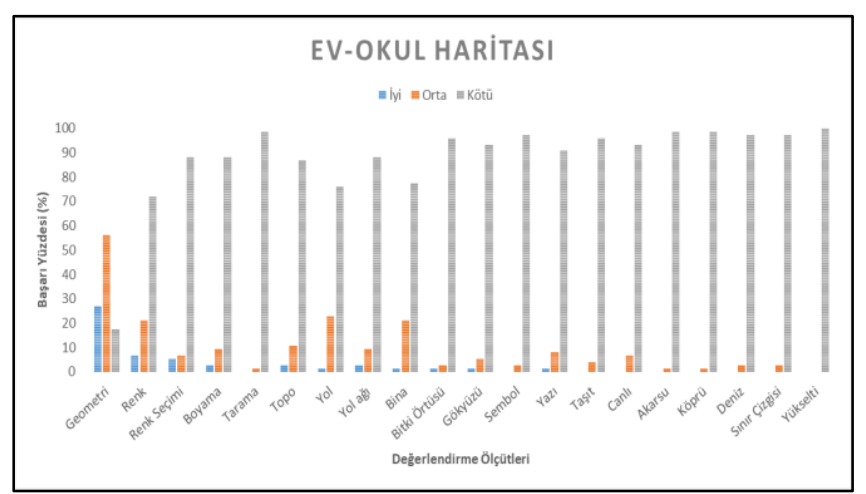

Şekil 2. Ev-okul haritası değerlendirme ölçütlerine göre birinci sınıf öğrencilerinin başarı yüzdeleri

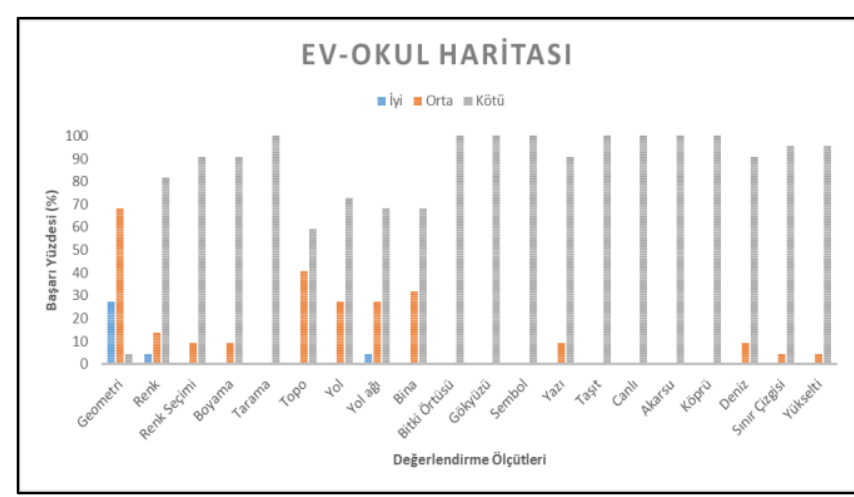

Şekil 3. Ev-okul haritası değerlendirme ölçütlerine göre ikinci sınıf öğrencilerinin başarı yüzdeleri 


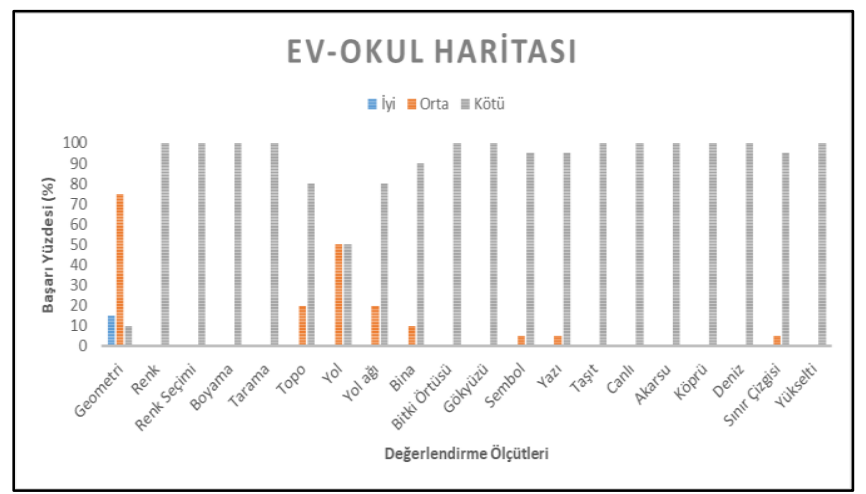

Şekil 4. Ev-okul haritası değerlendirme ölçütlerine göre üçüncü sınıf öğrencilerinin başarı yüzdeleri

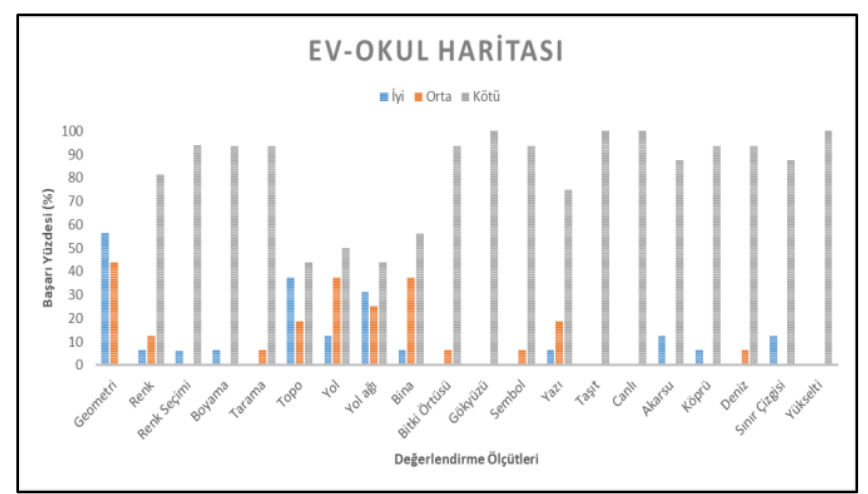

Şekil 5. Ev-okul haritası değerlendirme ölçütlerine göre dördüncü sınıf öğrencilerinin başarı yüzdeleri

Öğrencilerin aldıkları toplam puanlara göre başarı aralıkları (İyi: 15-60, Orta: 5-15, Zayıf: 0-5) belirlenmiş ve başarı analizleri yapılmıştır (Tablo 2).

Tablo 2. Birinci, ikinci, üçüncü ve dördüncü sınıf öğrencileri tarafından çizilen iyi, orta ve zayıf nitelikte ev-okul haritası başarı yüzdeleri

\begin{tabular}{lccc}
\hline Sinıflar & İyi & Orta & Zayıf \\
\hline 1. Sinıf & 22,7 & 73,3 & 4 \\
\hline 2. Sinıf & 4,5 & 95,5 & 0 \\
\hline 3. Sinıf & 5 & 95 & 0 \\
\hline 4. Sinıf & 43,8 & 56,2 & 0 \\
\hline
\end{tabular}

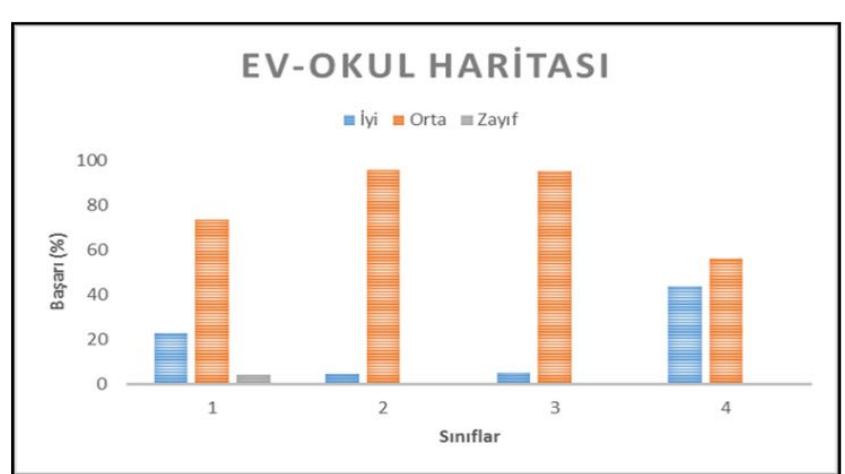

Şekil 6. Birinci, ikinci, üçüncü ve dördüncü sınıf öğrencileri tarafından çizilen iyi, orta ve zayıf nitelikte ev-okul haritası başarı yüzdeleri

Öğrencilerin aldıkları toplam puanlara göre analiz sonuçları grafik olarak Şekil 6'da; iyi, orta ve zayıf olarak nitelendirilebilecek birer örnek harita ise Sekil 7, 8 ve 9'da gösterilmiştir.

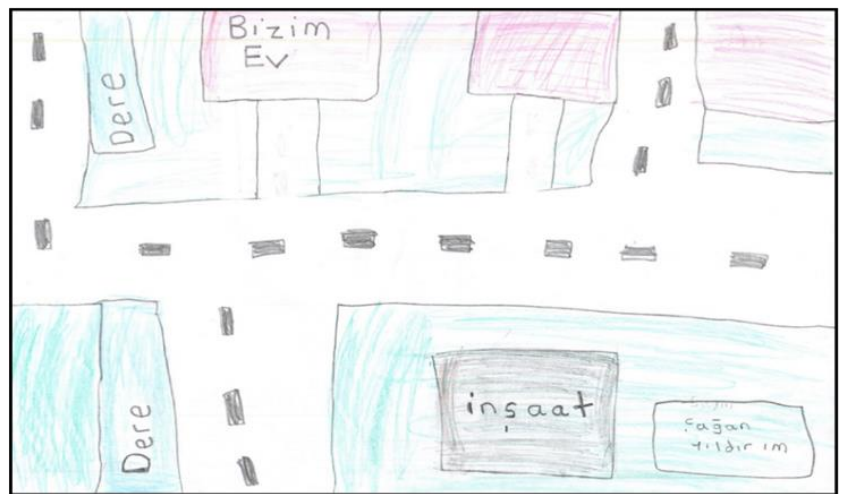

Şekil 7. Analiz sonuçlarına göre 40 puan alan ve iyi olarak nitelendirilebilecek bir ev-okul haritası (Dördüncü sınıf öğrencisi tarafından çizilmiştir.)

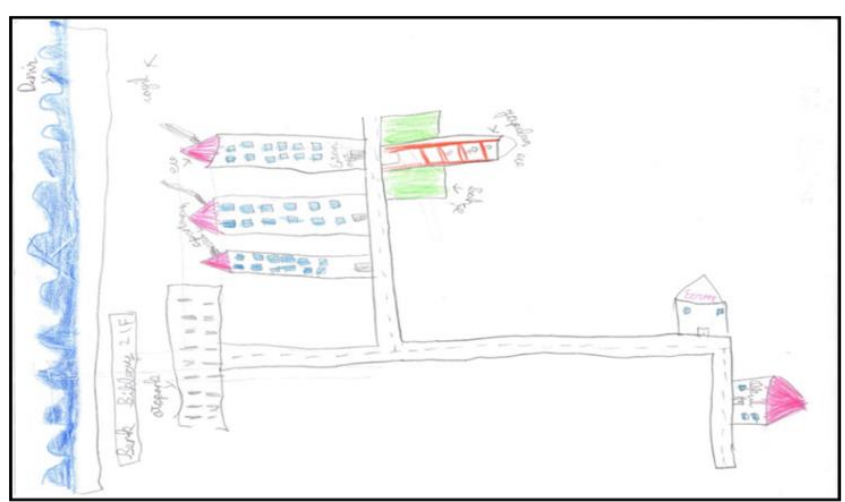

Şekil 8. Analiz sonuçlarına göre 25 puan alan ve orta olarak nitelendirilebilecek bir ev-okul haritası (İkinci sınıf öğrencisi tarafından çizilmiştir.)

Sekil 9. Analiz sonuçlarına göre 4 puan alan ve zayıf olarak nitelendirilebilecek bir ev-okul haritası (Birinci sınıf öğrencisi tarafından çizilmiştir.)

Bir 4. sınıf öğrencisi tarafından çizilen Şekil 7'deki harita; geometrik özellikleri, renklendirilmesi ve gerçekçiliği bakımından diğer haritalar arasından öne çıkmıștır. Bu nedenle bașarılı bir ev-okul haritası olarak nitelendirilmiştir. Bir 2. sınıf öğrencisi tarafından çizilen Şekil 8'deki haritada bina gösterimlerinin planimetrik olmadığı görünmektedir. Her ne kadar coğrafi özellikler bakımından doğru olsa da orta seviye olarak nitelendirilebilecek bir haritadır. Bir 1. sınıf öğrencisi tarafından çizilen ve geometri, renk, vb. tüm ölçütlere göre başarısız olarak değerlendirilen bir harita ise Şekil 9'da görünmektedir. 


\section{2. İkinci Aktivite: Dünya Haritası Çizimi}

Çocukların gördükleri bir haritayı hayal güçleri aracılığıyla kağıda nasıl yansıttıkları test edilmiştir. Dünya haritalarının ve atlasların çocukların akıllarında kalıcı yer ettiği bilinmektedir (Petchenik, 1987). Bu doğrultuda, Şekil 10'da görünen Dünya haritası tahtaya asılmış ve çocuklardan Dünya haritasını incelemeleri istenmiştir. Bazı çocuklar yanına gelerek, dokunarak ve sorarak haritayı incelemișlerdir. Daha sonra çocuklardan dünya haritasını zihinlerinde canlandırdıkları gibi çizmeleri istenmiştir.

Öğrenciler tarafından çizilen haritalar Tablo 3'teki ölçütlere göre incelenmiş ve her bir ölçüte göre $0-3$ arası puanlar (0: Yok, 1: Az, 2: Orta, 3: Oldukça) verilmiştir.

Ölçütlere göre verilen puanların toplamları hesaplanmış, başarı aralıkları (İyi: 2-6, Orta: 1-2, Zayıf: 01) belirlenmiş ve başarı analizleri yapılmıştır (Tablo 3).
Ölçütlere göre analiz sonuçları sınıf bazında grafik olarak Şekil 11, 12, 13 ve 14'de gösterilmiştir.

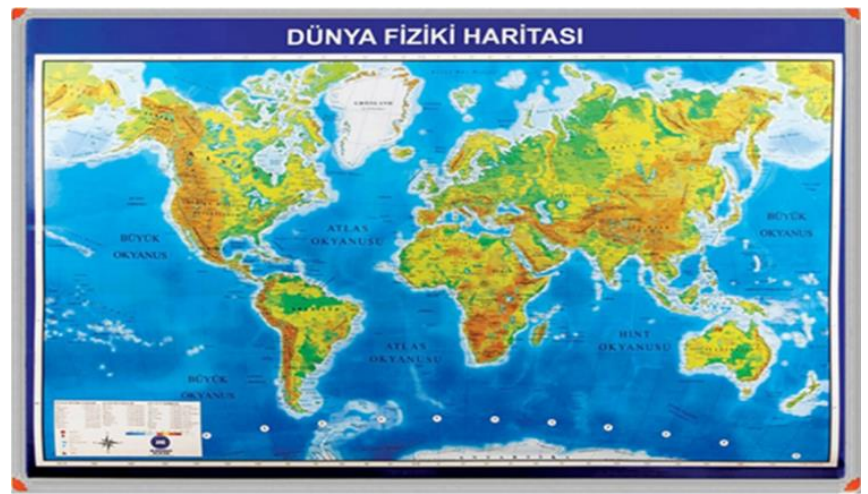

Şekil 10. Sınıf tahtasına asılan dünya haritası

Tablo 3. Dünya haritası değerlendirme ölçütlerine göre iyi, orta, zayıf nitelikte harita yüzdeleri

\begin{tabular}{lccc}
\hline \multicolumn{1}{c}{ Değerlendirme Ölçütleri } & İyi & Orta & Zayıf \\
\hline Geometri: Nokta, Çizgi, Poligon & 22,7 & 39,4 & 37,9 \\
\hline Renk: Siyah-Beyaz, Renkli & 5,3 & 11,4 & 83,3 \\
\hline Renk Seçimi: Doğru, Kısmen, Yanlıș & 0,8 & 11,4 & 87,9 \\
\hline Boyama & 4,5 & 8,3 & 87,1 \\
\hline Tarama & 0,8 & 1,5 & 97,7 \\
\hline Topolojik İlisskiler: Doğru, Kısmen, Yanlıș & 4,5 & 14,4 & 81,1 \\
\hline Gökyüzü (Güneș, Ay, Bulut) & 1,5 & 3 & 95,5 \\
\hline Sembol (Bayrak, vb.) & 0 & 0 & 100 \\
\hline Yazı & 0,8 & 6,8 & 92,4 \\
\hline Deniz & 5,3 & 8,3 & 86,4 \\
\hline Yükselti (Dağ, Tepe) & 0 & 1,5 & 98,5 \\
\hline
\end{tabular}

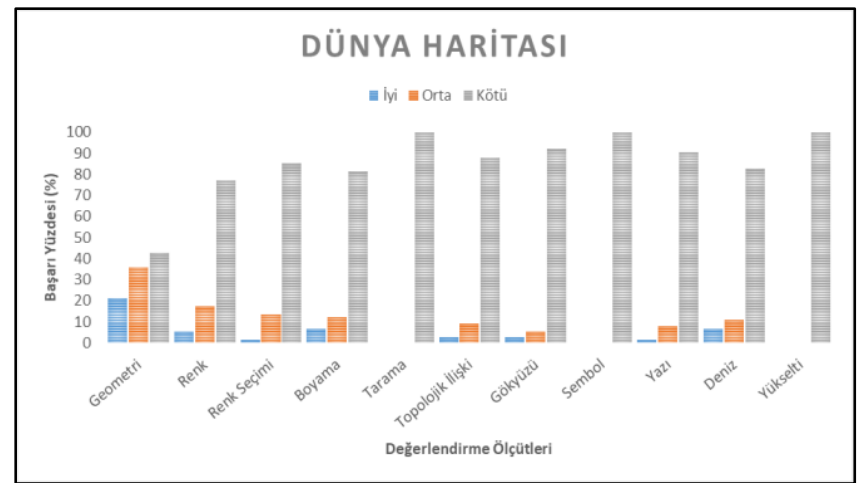

Şekil 11. Dünya haritası değerlendirme ölçütlerine göre birinci sınıf öğrencilerinin başarı yüzdeleri

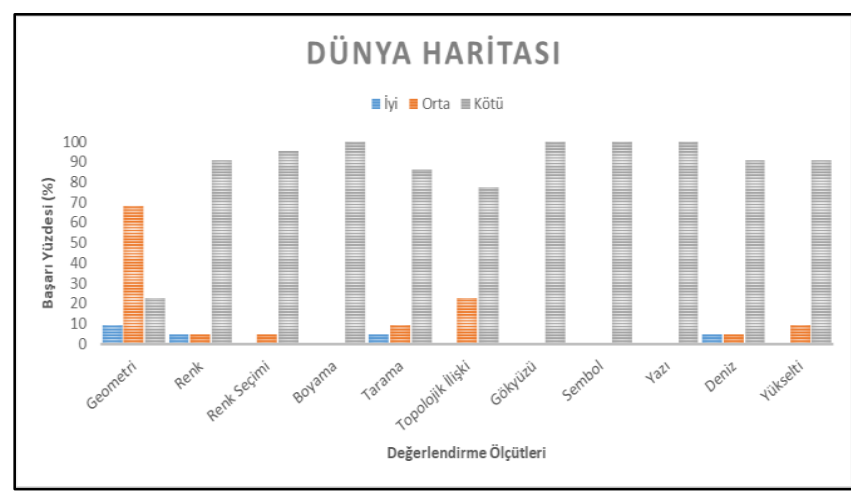

Şekil 12. Dünya haritası değerlendirme ölçütlerine göre ikinci sınıf öğrencilerinin başarı yüzdeleri

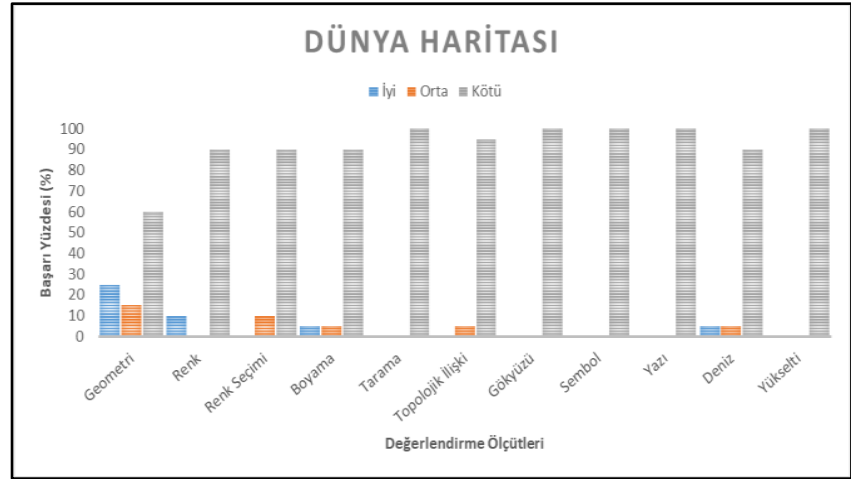

Şekil 13. Dünya haritası değerlendirme ölçütlerine göre üçüncü sınıf öğrencilerinin başarı yüzdeleri

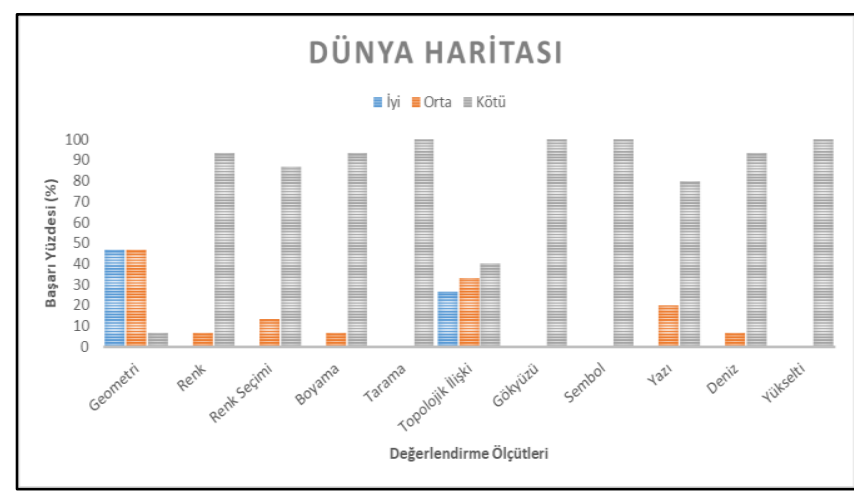

Şekil 14. Dünya haritası değerlendirme ölçütlerine göre dördüncü sınıf öğrencilerinin başarı yüzdeleri 
Öğrencilerin aldıkları toplam puanlara göre başarı aralıkları (İyi: 10-40, Orta: 5-10, Zayıf: 0-5) belirlenmiş ve başarı analizleri yapılmıştır (Tablo 4).

Tablo 4. Birinci, ikinci, üçüncü ve dördüncü sınıf öğrencileri tarafından çizilen iyi, orta ve zayıf nitelikte dünya haritası bașarı yüzdeleri

\begin{tabular}{lccc}
\hline Sınıflar & İyi & Orta & Zayıf \\
\hline 1. Sinıf & 17,3 & 44 & 38,7 \\
\hline 2. Sinıf & 13,6 & 68,2 & 18,2 \\
\hline 3. Sinıf & 10 & 35 & 55 \\
\hline 4. Sinıf & 40 & 53,3 & 6,7 \\
\hline
\end{tabular}

Öğrencilerin aldıkları toplam puanlara göre analiz sonuçları grafik olarak Şekil 15'te; iyi, orta ve zayıf olarak nitelendirilebilecek birer örnek harita ise Șekil 16, 17 ve 18 'de gösterilmiştir.

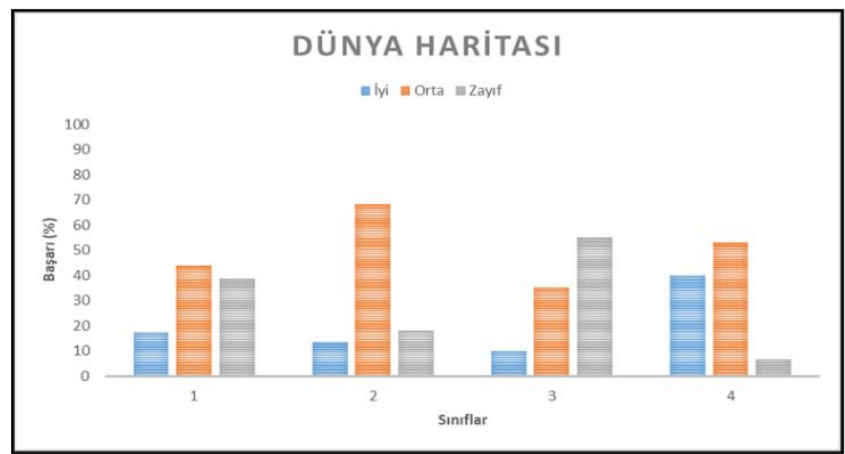

Şekil 15. Birinci, ikinci, üçüncü ve dördüncü sınıf ögrrencileri tarafından çizilen iyi, orta ve zayıf nitelikte dünya haritası başarı yüzdeleri

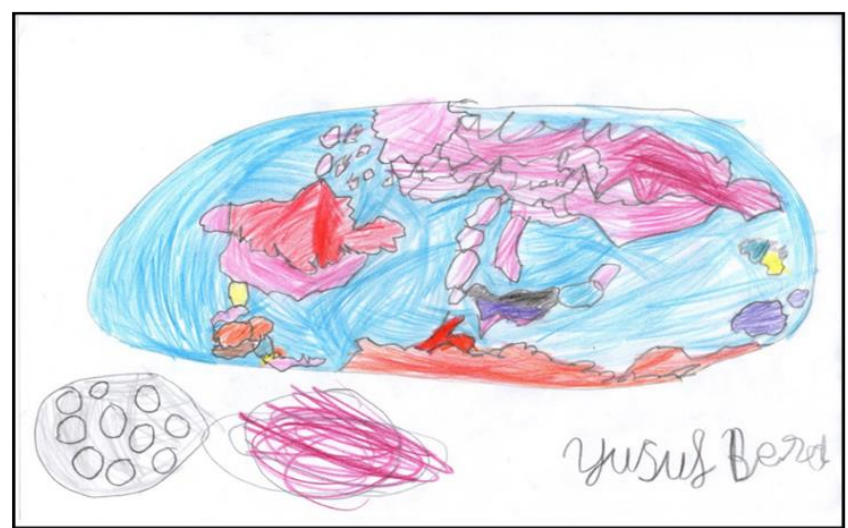

Şekil 16. Analiz sonuçlarına göre 22 puan alan ve iyi olarak nitelendirilebilecek bir dünya haritası (Birinci sınıf öğrencisi tarafından çizilmiştir.)

Şekil 16'daki haritayı çizen 1. sınıf öğrencisi geometrik özellikleri bakımından olmasa bile renklendirme ve tasarım bakımından başarılıdır. Ayrıca diğer gök cisimlerini de çizmesi, haritasının bir Dünya haritası olduğunu kanitlama çabası gibi değerlendirilebilir. Şekil 17'deki haritayı çizen 1. sınıf öğrencisi ise her ne kadar geometrik olarak doğru bir harita çizememiş olsa da sanatsal bir bakış açısına sahip gibi gözükmektedir. Şekil 18'deki haritayı çizen 1. sınıf öğrencisi ise sadece sınırları algılamış gibi gözükmektedir.

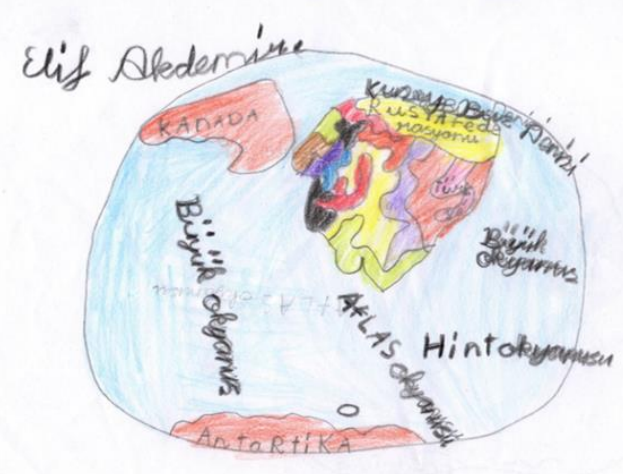

Şekil 17. Analiz sonuçlarına göre 20 puan alan ve orta olarak nitelendirilebilecek bir dünya haritası. (Birinci sınıf öğrencisi tarafından çizilmiştir.)

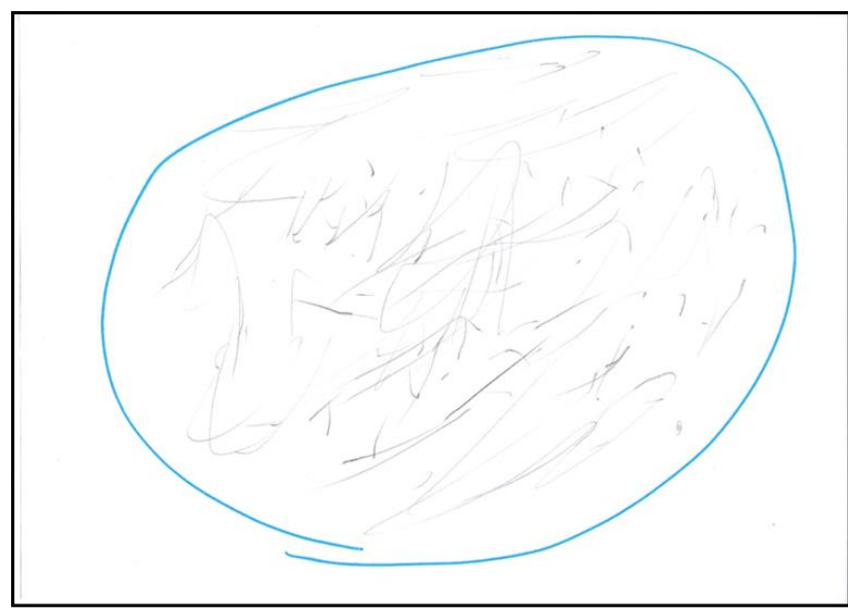

Şekil 18. Analiz sonuçlarına göre 0 puan alan ve zayıf olarak nitelendirilebilecek bir dünya haritası. (Birinci sınıf öğrencisi tarafından çizilmiş̧tir.)

\section{3. Üçüncü Aktivite: Define Haritası}

Çocukların harita okumadaki becerilerini test etmek için son olarak define haritası aktivitesi yapılmıştır. Define haritası aktivitesi için sınıfın belli bir noktasına bir cisim saklanmış ve sınıf krokisi yardımıyla bu cismi bulmaları istenmiştir. Çizilen sınıf krokisi Şekil 19'da görünmektedir. Çocukların tamamı saklı cismi bulabilmiştir.

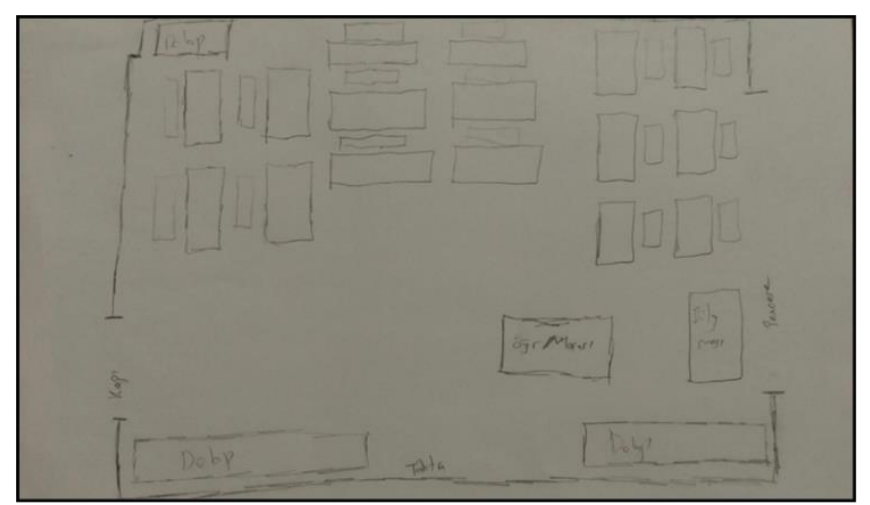

Şekil 19. Define haritası aktivitesinde kullanılan kroki

\section{SONUÇLAR}

Ev-okul haritası çiziminde en başarılı öğrenciler beklendiği gibi- dördüncü sınıf öğrencileri olmuștur. 
Ancak, ikinci sırada üçüncü sınıf öğrencileri değil, birinci sınıf öğrencileri yer almıştır. Üçüncü sınıf öğrencileri üçüncü sırada, ikinci sınıf öğrencileri dördüncü sırada yer almıştır. Birinci sınıf öğrencilerinin, ikinci ve üçüncü sınıf öğrencilerinin önüne geçmiş olması beklenmeyen bir sonuçtur. Ev-okul haritalarının büyük kısmı orta nitelikte olmuştur. Orta nitelikli haritalar bakımından sıralama; ikinci sınıf, üçüncü sınıf, birinci sınıf ve dördüncü sınıf öğrencileri şeklinde olmuştur. Birinci sınıflarda çizilen haritaların çok az bir kısmı zayıf nitelikte iken, ikinci, üçüncü ve dördüncü sınıflarda zayıf nitelikte harita çizilmemiştir. Aktivitelerin olabildiğince eşit imkân ve koşullarda yapılmış olmasına rağmen, özellikle iyi nitelikte haritalar bakımından beklenmeyen bir sonucun çıkmış olması ancak başka gerekçelerle (sosyolojik, psikolojik, pedagojik, vd.) açıklanabilir. Her şeye rağmen, birinci sınıflarda çizilen haritaların çok az bir kısmının zayıf nitelikte olması, ikinci, üçüncü ve dördüncü sınıflarda ise zayıf nitelikte harita çizilmemiş olması sevindiricidir. Sonuç olarak, birinci, ikinci, üçüncü ve dördüncü sınıf öğrencilerinin çoğunluğu orta nitelikte ev-okul haritası çizme becerisine sahiptir.

İyi nitelikte dünya haritası çiziminde başarı sıralaması; dördüncü sınıf, birinci sınıf, ikinci sınıf ve üçüncü sınıf öğrencileri şeklinde olmuştur. Dördüncü sınıf öğrencileri birinci sırada yer alması beklenen bir sonuçtur ancak diğer sınıfların sıralaması beklenen bir sonuç değildir. Birinci, ikinci ve dördüncü sınıf öğrencilerinin çizdiği dünya haritalarının çoğu orta nitelikte iken, üçüncü sınıf öğrencilerinin çizdiği dünya haritalarının çoğu zayıf nitelikte olmuștur.

Ev-okul haritası aktivitesi ile dünya haritası aktivitesi karşılaştırıldığında, öğrenciler ev-okul haritası aktivitesinde daha başarılı olmuştur. $\mathrm{Bu}$ sonuç şöyle yorumlanabilir: İlkokul öğrencileri küçük yeryüzü parçalarını zaten düzlem kabul ediyor ve bu nedenle yine bir düzlem yüzey olan kâğıda aktarmada zorlanmıyor olabilirler. Oysaki, küre benzeri bir şekil olduğunu bildikleri dünyayı, harita kavramını ve projeksiyon yöntemlerini tam olarak bilmedikleri için bir düzlem yüzeyde (tahtada asılı haritada) görmeyi yadırgıyor, haritada gördükleri ile gerçek dünyayı eşleyemiyor ve bu nedenle haritada gördüklerini bile kağıda aktarmada zorlanıyor, bilinçli bir çizim yapamıyor olabilirler. Ayrıca, ölçek farkındalığı bakımından, ilkokul öğrencilerinin genel olarak büyük ölçek düzeyinde oldukları söylenebilir. Son olarak, ilkokullarda harita eğitimine daha fazla önem ve yer verilmesi önerilebilir.

\section{ARAŞTIRMACILARIN KATKI ORANI}

Halil İbrahim Şenol: Literatür tarama, Deneyler, Veri analizi, Makaleyi yazma; Türkay Gökgöz: Çalışmayı tasarlama, Sonuçları yorumlama, Makale yazma

\section{ÇATIŞMA BEYANI}

Yazarlar arasında herhangi bir çıkar çatışması bulunmamaktadır.

\section{KAYNAKÇA}

Carswell R J B (1970). Children's Abilities in Topographic Map https://files.eric.ed.gov/fulltext/ED043557.pdf

Daggs D G (1986). Pyramid of Places: Children's Understanding of Geographic Hierarchy."

Harwood D \& Jackie M (1996). Young Children's Understanding of Nested Hierarchies of Place Relationships. International Research in Geographical \& Environmental Education 5(1):3-29. https://www.tandfonline.com/doi/abs/10.1080/10 382046.1996.9964985

Harwood D \& Kay R (2001). Assessing Young Children's Freehand Sketch Maps of the World." International Research in Geographical and Environmental Education 10(1):20-45. https://www.tandfonline.com/doi/abs/10.1080/10 382040108667422

Harwood D \& Margaret U (1999). Assessing Progression in Primary Children's Map Drawing Skills. International Research in Geographical and Environmental Education 8(3):222-38. https://www.tandfonline.com/doi/abs/10.1080/10 382049908667613

Hennerdal P (2015). Beyond the Periphery: Child and Adult Understanding of World Map Continuity. Annals of the Association of American Geographers 105(4):773-90.

https://www.tandfonline.com/doi/full/10.1080/00 045608.2015.1022091

Jahoda G (1963). The Development of Children's Ideas About Country and Nationality: Part I: The Conceptual Framework. British Journal of Educational Psychology 33(1):47-60. https://bpspsychub.onlinelibrary.wiley.com/doi/ab s/10.1111/j.2044-8279.1963.tb00562.x

Joshi M S, Morag M \& Wakefield C (1999). Children's Journey to School: Spatial Skills, Knowledge and Perceptions of the Environment. British Journal of Developmental Psychology 17(1):125-39. https://bpspsychub.onlinelibrary.wiley.com/doi/ab s/10.1348/026151099165195

Kızılçaoğlu A (2007). HARITA BECERİLERINE PEDAGOJIK BİR BAKIŞ. Selçuk Üniversitesi Sosyal Bilimler Enstitüsü Dergisi (18):341-58. http://dergisosyalbil.selcuk.edu.tr/susbed/article/vi ew/455

Ooms K, Philippe De M, Lien D, Nina Van der V, Nico Van de W \& Stephanie V (2016). Education in Cartography: What Is the Status of Young People's Map-Reading Skills? Cartography and Geographic Information Science 43(2):134-53. https://www.tandfonline.com/doi/full/10.1080/15 230406.2015.1021713

Petchenik B B (1987). Fundamental considerations about atlases for children. Cartographica: The International Journal for Geographic Information and Geovisual-ization,

$24(1), 16-23$ https://www.utpjournals.press/doi/abs/10.3138/T 813-3545-5444-6G81

Piaget J \& Inhelder B (1956). The child's conception of space. Routledge and Kegan Paul, London. 
Piche D (1977). The Geographical Understanding of Children Aged 5 to 8 Years. https://ethos.bl.uk/OrderDetails.do?uin=uk.bl.ethos. 261176

Piche D (1981). The Spontaneous Geography of the Urban Child. Geography and the Urban Environment: Progress in Research and Applications 4:229-56.

Sena C C R G D \& Carmo W R D (2020). School cartography in Brazil and its inclusive perspective. International Journal of Cartography, 6(3), 316-330. https://www.tandfonline.com/doi/full/10.1080/23 729333.2020 .1824565

Sönmez Ö F \& Bülent A (2013). CUMHURIYETTEN GÜNÜMÜZE İLKÖĞRETIM PROGRAMLARINDA HARITA BECERILERİ. Türkiye Sosyal Araștırmalar Dergisi 171(171):269-88. https://dergipark.org.tr/en/pub/tsadergisi/issue/2 $1497 / 230500$

Şenol H İ \& Gökgöz T (2018). A Case Study on Map Activities with Children of Kindergarten Age. 7th International Conference on Cartography and GIS, Sozopol, Bulgaristan, 18-23 Haziran 2018, 202-209. https://www.researchgate.net/publication/328686 567

Şenol H İ \& Gökgöz T (2020). Ortaokul Çocuklarının Harita Becerilerini Ölçme ve Değerlendirmeye Yönelik Bir Vaka Çalışması. Harran Üniversitesi Mühendislik Dergisi, 5(3), 157-174. https://dergipark.org.tr/en/pub/humder/issue/584 $94 / 770944$

Towler J 0 (1970). The Elementary School Child's Concept of Reference Systems. Journal of Geography 69(2):89-93. https://www.tandfonline.com/doi/abs/10.1080/00 221347008981757

Towler T O \& L D N (1968). The Elementary School Child's Concept of Scale. Journal of Geography 67(1):24-28.

https://www.tandfonline.com/doi/abs/10.1080/00 221346808981035

Trifonoff K M (1995). Going beyond Location: Thematic Maps in the Early Elementary Grades. Journal of Geography 94(2):368-74. https://www.tandfonline.com/doi/abs/10.1080/00 221349508979745

Weber A, Bernhard J, Matthias W, Juliane C, Philipp M \& Lorenz H (2010). Cartography Meets Gaming: Navigating Globes, Block Diagrams and 2D Maps with Gamepads and Joysticks. The Cartographic Journal 47(1):92-100. https://www.tandfonline.com/doi/abs/10.1179/00 0870409X12472347560588

Wiegand P (1995). Young Children's Freehand Sketch Maps of the World. International Research in Geographical \& Environmental Education 4(1):19-28. https://www.tandfonline.com/doi/abs/10.1080/10 382046.1995 .9964956

Wiegand P \& Bernadette S (1997). Children's Relief Maps of Model Landscapes. British Educational Research Journal 23(2):179-92.

Windiastuti R (2012). Map Drawing Competition for Children in Indonesia. 255-67 in Maps for the Future. Springer.

https://link.springer.com/chapter/10.1007/978-3642-19522-8_21 